\title{
Preliminary Interpretation on Detailed Magnetovariational Profilings in the Northern Tohoku District
}

\author{
Yasuo OGAWA \\ Geological Survey of Japan, 1-1-3 Higashi, Yatabe, Ibaraki, Japan
}

(Received April 23, 1987; Revised June 26, 1987)

\section{Introduction}

Many authors have studied resistivity models beneath the Tohoku district by use of geomagnetic variations. KATO et al. (1971) found large negative $\Delta Z / \Delta H$ values in the northern Tohoku district and attributed their cause to the undulation of the conductor. Their conclusion is that the depth to the upper surface of the conductive layer decreases northward along the island arc. This anomaly was named as "Northeastern Japan anomaly". However, YAMASHITA and YoKOYAMA (1976) pointed out that this anomaly is primarily due to the current channeling through the Tsugaru strait to the north of this district.

This district is a typical island arc and many authors have studied $2 D$ resistivity models across the island arc. HoNKURA (1974) and OGAWA et al. (1986) used GDS, RESEARCH Group FOR Crustal Resistivity STRUCTURe, JAPAN (1983), SATO and SAITO (1987) and OGAWA (1987) used MT, and UTADA (1987) used both GDS and MT. Most of these previous studies are based on natural signals at periods longer than $300 \mathrm{sec}$. Their targets were mainly the resistivity structure of the upper mantle.

In 1984 and 1985, magnetotelluric and magnetovariational observations in the period range from $0.05 \mathrm{sec}$ to $256 \mathrm{sec}$ were carried out in the northern Tohoku district. The purpose of this survey is to delineate deep and regional crustal resistivity structure. I used signals of shorter periods than those in previous studies. I also tried to cover the area sufficiently. Figure 1 shows 37 site locations where observations were carried out for ULF band (period range from 4 to $256 \mathrm{sec}$ ).

Two-dimensional interpretation of data obtained in 1984 were already described by OGAWA (1987). Apparent resistivity data themselves are affected by the shallow resistivity distribution. He paid special attention to the anisotropy in the phase values of impedance. From $2 D$ forward modelings, he concluded that the lower crust below the island arc is conductive $(10 \mathrm{ohm} \cdot \mathrm{m}$ to $300 \mathrm{ohm} \cdot \mathrm{m})$ and that the western lower crust is more conductive than the eastern one. He assumed two-dimensionality without paying much attention to three-dimensionality.

In order to investigate three-dimensional deep conductivity anomalies, the magnetovariational method is preferable to magnetotelluric method, because electric fields are often affected by shallow localized structure. In the present study, I 


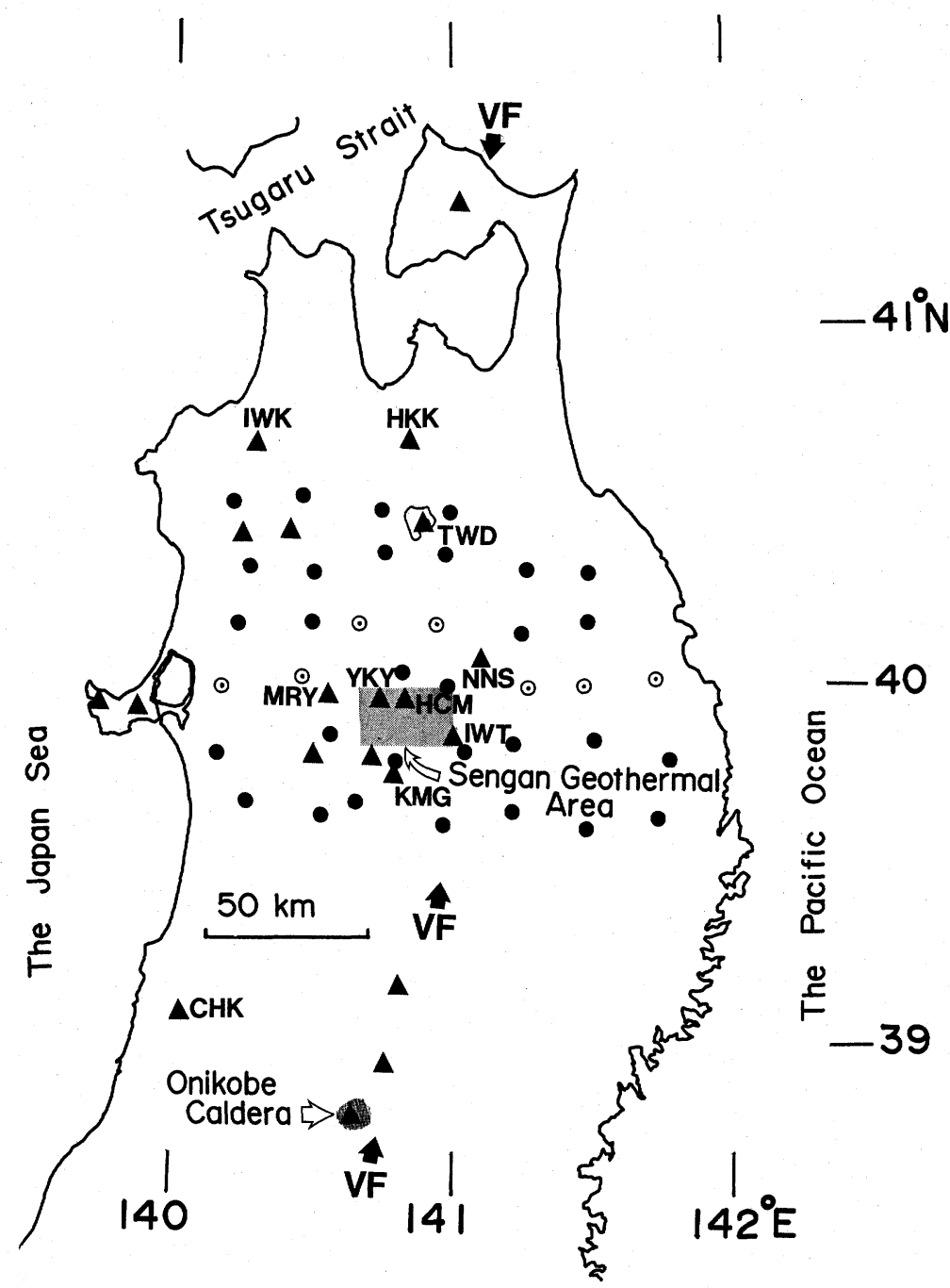

Fig. 1. Distribution of sites where geomagnetic variations were observed in the period range from 4 to $256 \mathrm{sec}$. Triangles denote Quaternary volcanoes (after GEOLOGICAL SURVEY OF JAPAN, 1982). See also Table 1 for abbreviation. VF stands for volcanic front. Two shaded areas denote geothermal fields where detailed magnetotelluric observations were carried out (OGAWA et al., 1987a; OGAWA and UCHIDA, 1987). 
Table 1. Abbreviation table for the names of major Quaternary volcanoes in Fig. 1.

\begin{tabular}{ll}
\hline CHK & Mt. Choukaisan \\
HCM & Mt. Hachimantai \\
HKK & Mt. Hakkoudasan \\
IWK & Mt. Iwakisan \\
IWT & Mt. Iwatesan \\
KMG & Mt. Komagatake \\
MRY & Mt. Moriyoshizan \\
NNS & Mt. Nanashigure \\
TWD & Towada Caldera \\
YKY & Mt. Yakeyama \\
\hline
\end{tabular}

attempted qualitative three-dimensional interpretation from the mapping of induction vectors.

\section{Data}

As shown in Fig. 1, observations were carried out at 7 stations (open circles) in 1984 and at 30 stations (solid circles) in 1985. Data were aquired for nearly two days at each station with sampling interval of $1 \mathrm{sec}$. As for data obtained in 1985, synchronous measurements were carried out at two simultaneous stations.

Table 2. Site locations and geomagnetic transfer functions. $A$ and $B$ are defined as $H_{z}=A H_{x}+B H_{y}$, where $H_{x}, H_{y}, H_{z}$ are north, east, downward components of magnetic field. Estimated error is calculated from $95 \%$ confidence limit.

\begin{tabular}{|c|c|c|c|c|c|c|c|c|c|}
\hline \multirow{2}{*}{ Site } & \multirow{2}{*}{ Latitude } & \multirow{2}{*}{ Longitude } & \multirow{2}{*}{$\begin{array}{c}\text { Period } \\
(\mathrm{sec})\end{array}$} & \multicolumn{3}{|c|}{$A$} & \multicolumn{3}{|c|}{$B$} \\
\hline & & & & Real & Imag & Error & Real & Imag & Error \\
\hline \multirow[t]{3}{*}{1} & $39^{\circ} 59^{\prime} 31^{\prime \prime}$ & $140^{\circ} 11^{\prime} 01^{\prime \prime}$ & 256 & -0.25 & 0.12 & 0.17 & 0.40 & 0.09 & 0.18 \\
\hline & & & 64 & -0.28 & -0.02 & 0.12 & 0.46 & -0.05 & 0.10 \\
\hline & & & 16 & -0.23 & 0.15 & 0.13 & 0.39 & -0.03 & 0.08 \\
\hline \multirow[t]{3}{*}{2} & $40^{\circ} 04^{\prime} 06^{\prime \prime}$ & $140^{\circ} 28^{\prime} 54^{\prime \prime}$ & 256 & -0.12 & 0.14 & 0.11 & 0.11 & 0.18 & 0.22 \\
\hline & & & 64 & -0.06 & 0.08 & 0.06 & 0.10 & 0.12 & 0.13 \\
\hline & & & 16 & -0.01 & 0.03 & 0.09 & 0.27 & 0.01 & 0.15 \\
\hline \multirow[t]{3}{*}{3} & $40^{\circ} 10^{\prime} 13^{\prime \prime}$ & $140^{\circ} 41^{\prime} 27^{\prime \prime}$ & 256 & -0.24 & 0.00 & 0.10 & -0.09 & 0.05 & 0.10 \\
\hline & & & 64 & -0.11 & 0.03 & 0.05 & 0.05 & -0.04 & 0.10 \\
\hline & & & 16 & -0.19 & -0.06 & 0.04 & -0.04 & -0.11 & 0.06 \\
\hline \multirow[t]{3}{*}{4} & $40^{\circ} 10^{\prime} 08^{\prime \prime}$ & $140^{\circ} 58^{\prime} 24^{\prime \prime}$ & 256 & -0.13 & 0.16 & 0.11 & -0.08 & 0.01 & 0.12 \\
\hline & & & 64 & 0.05 & 0.14 & 0.08 & 0.00 & -0.17 & 0.13 \\
\hline & & & 16 & 0.12 & 0.12 & 0.09 & -0.33 & -0.22 & 0.14 \\
\hline \multirow[t]{3}{*}{5} & $39^{\circ} 59^{\prime} 15^{\prime \prime}$ & $141^{\circ} 17^{\prime} 02^{\prime \prime}$ & 256 & -0.31 & 0.14 & 0.05 & -0.09 & 0.12 & 0.08 \\
\hline & & & 64 & -0.20 & 0.08 & 0.06 & -0.02 & 0.09 & 0.09 \\
\hline & & & 16 & -0.20 & 0.06 & 0.05 & 0.02 & 0.07 & 0.07 \\
\hline
\end{tabular}


Table 2. (continued)

\begin{tabular}{|c|c|c|c|c|c|c|c|c|c|}
\hline \multirow{2}{*}{ Site } & \multirow{2}{*}{ Latitude } & \multirow{2}{*}{ Longitude } & \multirow{2}{*}{$\begin{array}{l}\text { Period } \\
(\mathrm{sec})\end{array}$} & \multicolumn{3}{|c|}{$A$} & \multicolumn{3}{|c|}{$B$} \\
\hline & & & & Real & Imag & Error & Real & Imag & Error \\
\hline \multirow[t]{3}{*}{6} & $39^{\circ} 59^{\prime} 28^{\prime \prime}$ & $141^{\circ} 29^{\prime} 11^{\prime \prime}$ & 256 & -0.31 & 0.14 & 0.06 & -0.08 & 0.18 & 0.09 \\
\hline & & & 64 & -0.14 & 0.16 & 0.05 & -0.01 & 0.24 & 0.06 \\
\hline & & & 16 & -0.03 & 0.13 & 0.03 & 0.23 & 0.09 & 0.05 \\
\hline \multirow[t]{3}{*}{7} & $40^{\circ} 00^{\prime} 53^{\prime \prime}$ & $141^{\circ} 45^{\prime} 15^{\prime \prime}$ & 256 & -0.41 & 0.00 & 0.27 & -0.58 & 0.39 & 0.49 \\
\hline & & & 64 & -0.22 & 0.18 & 0.18 & -0.37 & 0.18 & 0.32 \\
\hline & & & 16 & -0.23 & 0.02 & 0.23 & -0.21 & 0.14 & 0.28 \\
\hline \multirow[t]{3}{*}{8} & $40^{\circ} 30^{\prime} 42^{\prime \prime}$ & $140^{\circ} 13^{\prime} 18^{\prime \prime}$ & 256 & -0.48 & 0.06 & 0.17 & 0.14 & -0.04 & 0.42 \\
\hline & & & 64 & -0.28 & 0.14 & 0.03 & 0.19 & -0.07 & 0.05 \\
\hline & & & 16 & -0.15 & 0.00 & 0.12 & 0.14 & -0.19 & 0.15 \\
\hline \multirow[t]{3}{*}{9} & $40^{\circ} 31^{\prime} 52^{\prime \prime}$ & $140^{\circ} 28^{\prime} 26^{\prime \prime}$ & 256 & -0.41 & 0.06 & 0.08 & -0.01 & -0.04 & 0.17 \\
\hline & & & 64 & -0.37 & 0.03 & 0.01 & 0.04 & -0.03 & 0.02 \\
\hline & & & 16 & -0.31 & 0.25 & 0.15 & 0.97 & -0.37 & 0.19 \\
\hline \multirow[t]{3}{*}{10} & $40^{\circ} 29^{\prime} 47^{\prime \prime}$ & $140^{\circ} 45^{\prime} 02^{\prime \prime}$ & 256 & -0.30 & 0.10 & 0.04 & -0.05 & 0.13 & 0.09 \\
\hline & & & 64 & -0.22 & 0.04 & 0.03 & -0.05 & -0.03 & 0.07 \\
\hline & & & 16 & -0.23 & 0.03 & 0.09 & -0.12 & -0.07 & 0.10 \\
\hline \multirow[t]{3}{*}{11} & $40^{\circ} 29^{\prime} 24^{\prime \prime}$ & $141^{\circ} 00^{\prime} 08^{\prime \prime}$ & 256 & -0.15 & 0.16 & 0.06 & -0.10 & -0.02 & 0.13 \\
\hline & & & 64 & -0.10 & 0.12 & 0.02 & -0.11 & -0.09 & 0.04 \\
\hline & & & 16 & -0.01 & 0.05 & 0.04 & -0.28 & -0.04 & 0.05 \\
\hline \multirow{3}{*}{12} & $40^{\circ} 20^{\prime} 04^{\prime \prime}$ & $140^{\circ} 16^{\prime} 42^{\prime \prime}$ & 256 & -0.02 & 0.25 & 0.08 & 0.12 & 0.03 & 0.11 \\
\hline & & & 64 & 0.16 & 0.16 & 0.04 & 0.15 & -0.16 & 0.12 \\
\hline & & & 16 & 0.34 & -0.04 & 0.20 & 0.13 & -0.17 & 0.21 \\
\hline \multirow[t]{3}{*}{13} & $40^{\circ} 19^{\prime} 17^{\prime \prime}$ & $140^{\circ} 30^{\prime} 35^{\prime \prime}$ & 256 & -0.10 & 0.15 & 0.07 & 0.12 & -0.01 & 0.11 \\
\hline & & & 64 & 0.01 & 0.14 & 0.04 & 0.07 & 0.00 & 0.04 \\
\hline & & & 16 & 0.00 & 0.17 & 0.08 & 0.12 & -0.05 & 0.12 \\
\hline \multirow[t]{3}{*}{14} & $40^{\circ} 22^{\prime} 19^{\prime \prime}$ & $140^{\circ} 45^{\prime} 42^{\prime \prime}$ & 256 & -0.21 & 0.11 & 0.08 & 0.02 & -0.10 & 0.13 \\
\hline & & & 64 & -0.17 & 0.05 & 0.03 & 0.02 & 0.02 & 0.06 \\
\hline & & & 16 & -0.17 & 0.09 & 0.11 & 0.21 & -0.06 & 0.26 \\
\hline \multirow[t]{3}{*}{15} & $40^{\circ} 22^{\prime} 09^{\prime \prime}$ & $140^{\circ} 58^{\prime} 54^{\prime \prime}$ & 256 & -0.20 & 0.12 & 0.06 & -0.08 & 0.02 & 0.10 \\
\hline & & & 64 & -0.17 & 0.05 & 0.04 & -0.15 & -0.10 & 0.07 \\
\hline & & & 16 & -0.12 & -0.04 & 0.05 & -0.32 & -0.14 & 0.06 \\
\hline \multirow[t]{3}{*}{16} & $40^{\circ} 19^{\prime} 34^{\prime \prime}$ & $141^{\circ} 16^{\prime} 30^{\prime \prime}$ & 256 & -0.56 & 0.22 & 0.18 & 0.04 & 0.19 & 0.15 \\
\hline & & & 64 & -0.41 & 0.17 & 0.09 & 0.13 & 0.11 & 0.09 \\
\hline & & & 16 & -0.31 & 0.17 & 0.09 & 0.17 & 0.02 & 0.05 \\
\hline \multirow[t]{3}{*}{17} & $40^{\circ} 18^{\prime} 47^{\prime \prime}$ & $141^{\circ} 29^{\prime} 59^{\prime \prime}$ & 256 & -0.83 & 0.18 & 0.15 & -0.14 & 0.34 & 0.13 \\
\hline & & & 64 & -0.66 & 0.19 & 0.08 & 0.09 & 0.28 & 0.10 \\
\hline & & & 16 & -0.28 & 0.15 & 0.09 & 0.52 & 0.24 & 0.06 \\
\hline \multirow[t]{3}{*}{18} & $40^{\circ} 10^{\prime} 29^{\prime \prime}$ & $140^{\circ} 14^{\prime} 24^{\prime \prime}$ & 256 & -0.28 & 0.12 & 0.11 & 0.18 & -0.02 & 0.16 \\
\hline & & & 64 & -0.12 & 0.11 & 0.07 & 0.34 & -0.12 & 0.12 \\
\hline & & & 16 & -0.06 & 0.02 & 0.11 & 0.19 & -0.18 & 0.12 \\
\hline 19 & $40^{\circ} 10^{\prime} 02^{\prime \prime}$ & $140^{\circ} 30^{\prime} 52^{\prime \prime}$ & 256 & -0.23 & 0.02 & 0.07 & 0.10 & 0.14 & 0.14 \\
\hline & & & 64 & -0.21 & 0.07 & 0.04 & 0.12 & 0.07 & 0.08 \\
\hline & & & 16 & -0.16 & 0.04 & 0.08 & 0.15 & 0.02 & 0.11 \\
\hline 20 & $40^{\circ} 08^{\prime} 54^{\prime \prime}$ & $141^{\circ} 15^{\prime} 20^{\prime \prime}$ & 256 & -0.42 & 0.13 & 0.05 & 0.04 & 0.14 & 0.05 \\
\hline & & & 64 & -0.32 & 0.09 & 0.02 & 0.06 & 0.07 & 0.02 \\
\hline & & & 16 & -0.26 & 0.16 & 0.16 & 0.18 & 0.04 & 0.18 \\
\hline 21 & $40^{\circ} 10^{\prime} 57^{\prime \prime}$ & $141^{\circ} 29^{\prime} 33^{\prime \prime}$ & 256 & -0.33 & 0.37 & 0.53 & 0.15 & 0.19 & 0.78 \\
\hline & & & 64 & -0.48 & 0.18 & 0.06 & 0.06 & 0.23 & 0.09 \\
\hline & & & 16 & -0.34 & 0.06 & 0.24 & 0.40 & 0.18 & 0.29 \\
\hline
\end{tabular}


Table 2. (continued)

\begin{tabular}{|c|c|c|c|c|c|c|c|c|c|}
\hline \multirow{2}{*}{ Site } & \multirow{2}{*}{ Latitude } & \multirow{2}{*}{ Longitude } & \multirow{2}{*}{$\begin{array}{l}\text { Period } \\
(\mathrm{sec})\end{array}$} & \multicolumn{3}{|c|}{$A$} & \multicolumn{3}{|c|}{$B$} \\
\hline & & & & Real & Imag & Error & Real & Imag & Error \\
\hline \multirow[t]{3}{*}{22} & $40^{\circ} 02^{\prime} 33^{\prime \prime}$ & $140^{\circ} 49^{\prime} 53^{\prime \prime}$ & 256 & -0.01 & 0.21 & 0.07 & 0.04 & 0.01 & 0.11 \\
\hline & & & 64 & 0.15 & 0.24 & 0.06 & 0.03 & -0.04 & 0.09 \\
\hline & & & 16 & 0.32 & 0.19 & 0.05 & 0.06 & 0.21 & 0.07 \\
\hline \multirow[t]{3}{*}{23} & $40^{\circ} 00^{\prime} 16^{\prime \prime}$ & $140^{\circ} 59^{\prime} 09^{\prime \prime}$ & 256 & 0.08 & 0.13 & 0.09 & 0.17 & 0.01 & 0.16 \\
\hline & & & 64 & 0.12 & 0.17 & 0.06 & -0.09 & 0.01 & 0.08 \\
\hline & & & 16 & 0.33 & 0.13 & 0.07 & -0.09 & 0.10 & 0.15 \\
\hline \multirow[t]{3}{*}{24} & $39^{\circ} 49^{\prime} 14^{\prime \prime}$ & $140^{\circ} 09^{\prime} 40^{\prime \prime}$ & 256 & -0.19 & 0.10 & 0.06 & 0.82 & 0.20 & 0.09 \\
\hline & & & 64 & -0.19 & 0.10 & 0.04 & 0.86 & 0.21 & 0.05 \\
\hline & & & 16 & -0.10 & 0.08 & 0.18 & 0.92 & -0.11 & 0.09 \\
\hline \multirow[t]{3}{*}{25} & $39^{\circ} 52^{\prime} 02^{\prime \prime}$ & $140^{\circ} 34^{\prime} 14^{\prime \prime}$ & 256 & -0.11 & 0.08 & 0.03 & 0.06 & 0.05 & 0.04 \\
\hline & & & 64 & -0.07 & 0.05 & 0.01 & 0.09 & 0.00 & 0.02 \\
\hline & & & 16 & 0.00 & 0.04 & 0.11 & 0.06 & -0.07 & 0.12 \\
\hline \multirow[t]{3}{*}{26} & $39^{\circ} 47^{\prime} 49^{\prime \prime}$ & $140^{\circ} 47^{\prime} 56^{\prime \prime}$ & 256 & 0.08 & 0.09 & 0.03 & 0.03 & 0.01 & 0.04 \\
\hline & & & 64 & 0.10 & 0.11 & 0.01 & 0.00 & -0.06 & 0.02 \\
\hline & & & 16 & 0.13 & 0.08 & 0.03 & -0.10 & -0.08 & 0.05 \\
\hline \multirow[t]{3}{*}{27} & $39^{\circ} 49^{\prime} 32^{\prime \prime}$ & $141^{\circ} 02^{\prime} 57^{\prime \prime}$ & 256 & -0.26 & 0.13 & 0.10 & -0.12 & 0.00 & 0.30 \\
\hline & & & 64 & -0.11 & 0.18 & 0.51 & -0.01 & 0.19 & 0.51 \\
\hline & & & 16 & -0.23 & -0.06 & 0.14 & 0.21 & 0.06 & 0.12 \\
\hline \multirow[t]{3}{*}{28} & $39^{\circ} 50^{\prime} 42^{\prime \prime}$ & $141^{\circ} 13^{\prime} 14^{\prime \prime}$ & 256 & -0.33 & -0.03 & 0.18 & 0.02 & 0.18 & 0.28 \\
\hline & & & 64 & -0.29 & -0.10 & 0.21 & 0.08 & 0.11 & 0.20 \\
\hline & & & 16 & -0.29 & -0.02 & 0.57 & 0.16 & 0.33 & 0.45 \\
\hline \multirow[t]{3}{*}{29} & $39^{\circ} 51^{\prime} 18^{\prime \prime}$ & $141^{\circ} 30^{\prime} 29^{\prime \prime}$ & 256 & -0.27 & 0.13 & 0.06 & -0.10 & 0.12 & 0.11 \\
\hline & & & 64 & -0.19 & 0.05 & 0.06 & -0.05 & 0.09 & 0.07 \\
\hline & & & 16 & 0.11 & 0.16 & 0.29 & 0.06 & -0.02 & 0.34 \\
\hline \multirow[t]{3}{*}{30} & $39^{\circ} 41^{\prime} 01^{\prime \prime}$ & $140^{\circ} 15^{\prime} 31^{\prime \prime}$ & 256 & -0.08 & 0.08 & 0.06 & 0.35 & 0.04 & 0.09 \\
\hline & & & 64 & -0.02 & 0.09 & 0.04 & 0.42 & -0.06 & 0.05 \\
\hline & & & 16 & 0.05 & 0.02 & 0.11 & 0.23 & -0.15 & 0.06 \\
\hline \multirow[t]{3}{*}{31} & $39^{\circ} 39^{\prime} 13^{\prime \prime}$ & $140^{\circ} 31^{\prime} 43^{\prime \prime}$ & 256 & 0.09 & 0.09 & 0.08 & 0.12 & -0.01 & 0.09 \\
\hline & & & 64 & 0.13 & 0.11 & 0.03 & 0.15 & 0.06 & 0.04 \\
\hline & & & 16 & 0.16 & 0.07 & 0.14 & 0.18 & -0.09 & 0.10 \\
\hline \multirow[t]{3}{*}{32} & $39^{\circ} 41^{\prime} 23^{\prime \prime}$ & $140^{\circ} 40^{\prime} 49^{\prime \prime}$ & 256 & -0.08 & 0.07 & 0.03 & 0.06 & 0.05 & 0.04 \\
\hline & & & 64 & -0.05 & 0.02 & 0.01 & 0.09 & 0.01 & 0.02 \\
\hline & & & 16 & -0.13 & 0.00 & 0.09 & 0.07 & -0.02 & 0.06 \\
\hline \multirow[t]{3}{*}{33} & $39^{\circ} 37^{\prime} 26^{\prime \prime}$ & $140^{\circ} 57^{\prime} 59^{\prime \prime}$ & 256 & -0.21 & 0.03 & 0.04 & 0.00 & 0.06 & 0.08 \\
\hline & & & 64 & -0.20 & -0.02 & 0.08 & 0.01 & -0.04 & 0.10 \\
\hline & & & 16 & -0.20 & -0.16 & 0.16 & -0.03 & -0.16 & 0.10 \\
\hline \multirow[t]{3}{*}{34} & $39^{\circ} 39^{\prime} 22^{\prime \prime}$ & $141^{\circ} 13^{\prime} 02^{\prime \prime}$ & 256 & -0.27 & 0.05 & 0.09 & -0.04 & 0.19 & 0.17 \\
\hline & & & 64 & -0.18 & -0.01 & 0.06 & 0.11 & 0.14 & 0.09 \\
\hline & & & 16 & -0.22 & -0.08 & 0.18 & 0.19 & 0.04 & 0.18 \\
\hline 35 & $39^{\circ} 36^{\prime} 14^{\prime \prime}$ & $141^{\circ} 29^{\prime} 27^{\prime \prime}$ & 256 & -0.22 & 0.06 & 0.03 & -0.23 & 0.07 & 0.05 \\
\hline & & & 64 & -0.18 & -0.05 & 0.04 & -0.09 & 0.08 & 0.08 \\
\hline & & & 16 & 0.06 & 0.19 & 0.34 & -0.15 & 0.13 & 0.31 \\
\hline 36 & $39^{\circ} 38^{\prime} 27^{\prime \prime}$ & $141^{\circ} 44^{\prime} 35^{\prime \prime}$ & 256 & 0.16 & 0.18 & 0.12 & -0.17 & 0.11 & 0.14 \\
\hline & & & 64 & 0.27 & 0.16 & 0.07 & -0.11 & 0.17 & 0.10 \\
\hline & & & 16 & 0.40 & 0.14 & 0.10 & 0.02 & 0.16 & 0.09 \\
\hline 37 & $39^{\circ} 47^{\prime} 55^{\prime \prime}$ & $141^{\circ} 46^{\prime} 49^{\prime \prime}$ & 256 & -0.26 & 0.08 & 0.06 & -0.40 & 0.12 & 0.09 \\
\hline & & & 64 & -0.12 & 0.13 & 0.04 & -0.35 & 0.15 & 0.05 \\
\hline & & & 16 & 0.00 & 0.05 & 0.05 & -0.21 & 0.26 & 0.06 \\
\hline
\end{tabular}


I first carefully checked all the time series and then carried out frequency analyses. Geomagnetic transfer functions were calculated following the selective stacking scheme of OGAWA et al. (1985). Table 2 shows the result of the analyses.

\section{Induction Vectors}

Induction vectors were derived in the period range from 4 to $256 \mathrm{sec}$. In the following, real parts of induction vectors for the periods of 256, 64, and $16 \mathrm{sec}$ are discussed in some detail.

\subsection{Induction vectors at the period of $256 \mathrm{sec}$}

Figure 2 shows the induction vectors at the period of $256 \mathrm{sec}$. The electric currents induced in the ocean affect the regional distribution of induction vectors. Induction vectors near the Japan Sea coast (sites 1, 24, and 30) and near the Pacific coast (sites 7,37, and 36) point to the ocean. In the northern part of the surveyed area (sites $8,9,10,11,16$, and 17), induction vectors point to the north. This is primarily due to the channeling current flowing through the Tsugaru strait as discussed by YAMASHITA and YOKOYAMA (1976).

However, it is difficult to explain the distribution of induction vectors only by the oceanic effect. There are two interesting features. The first is that the northward induction vectors near the volcanic front (sites 11, 15, 4, 23, 26, and 32) are significantly smaller than those to the east (sites 16, 20, 5, 27, and 33). We can see this feature from the north to the south in the surveyed area. Deep resistivity structure in the northern Tohoku district is characterized by two dimensional structure with north-south strike. The volcanic front can be a sharp resistivity boundary. The second is that the Sengan geothermal area (shaded zone) is delineated by anomalous induction vectors at the sites to the north (sites 22 and 23). We can infer the existence of low resistivity anomaly below the Sengan geothermal field.

\subsection{Induction vectors at the period of $64 \mathrm{sec}$}

Figure 3 shows the induction vectors at the period of $64 \mathrm{sec}$. General feature of induction vectors is similar to that at the period of $256 \mathrm{sec}$. The decrease of the regional northward components of induction vectors to the west of the volcanic front is more evident than that at the period of $256 \mathrm{sec}$. Moreover, the sites (sites 22 and 23), which are to the north of the Sengan geothermal area, show southward induction vectors. We can again infer the existence of low resistivity below the Sengan geothermal area.

\subsection{Induction vectors at the period of $16 \mathrm{sec}$}

Figure 4 shows the induction vectors at the period of $16 \mathrm{sec}$. The distribution of induction vectors reflects more local structure than those at longer periods. Regional oceanic effects such as the coastal effect and the strait effect are weak. The oceanic effect is significant only near the coastline, such as sites $1,24,30,7$, and 37 . There are two interesting features in this figure. The first one is the concentration of induction 


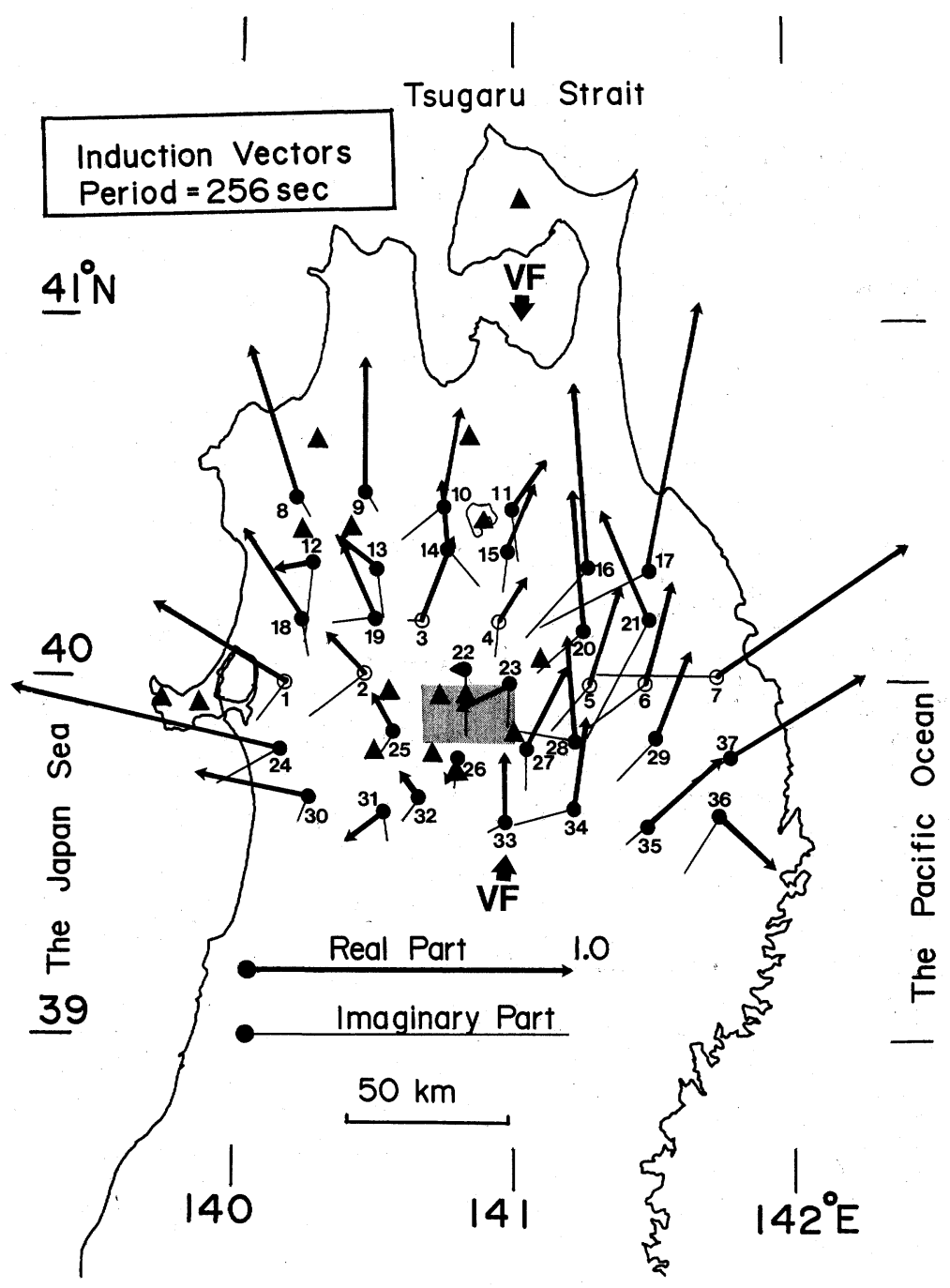

Fig. 2. Induction vectors at the period of $256 \mathrm{sec}$. Numbers denote site ID. Thick vectors and thin vectors are real and imaginary parts of induction vectors, respectively. The shaded area denotes the Sengan geothermal area.

vectors to a 'conductive belt'. I showed it by dots in Fig. 4. Let me refer to this anomaly as 'NTCB' (Northern Tohoku conductive belt). NTCB runs parallel to the volcanic front in the northern surveyed area and includes the Sengan geothermal area. Induction vectors at the western margin of NTCB (sites 11, 15, 4, and 23) point to the 


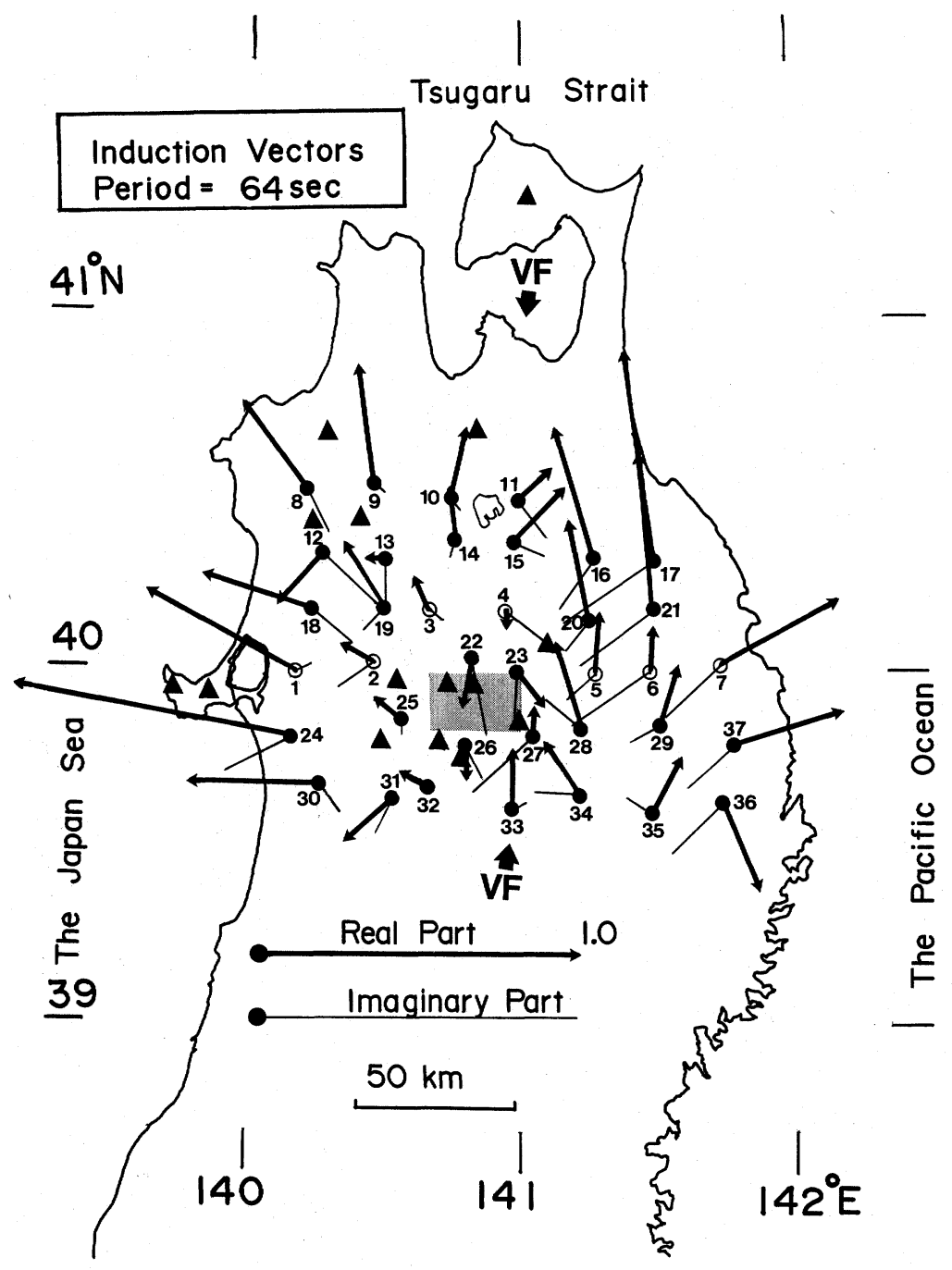

Fig. 3. Induction vectors at the period of $64 \mathrm{sec}$.

east. Those at the eastern margin of NTCB (sites 17, 21, 6, 28, and 34) point to the west. It is not clear at this moment that this anomaly is of deep origin or of shallow origin.

Induction vectors surrounding the Sengan geothermal area delineate the low resistivity anomaly below the Sengan geothermal area, as inferred from induction vectors at sites $22,23,27,33,34$, and 32 . The vector at site 25 also suggests the low 


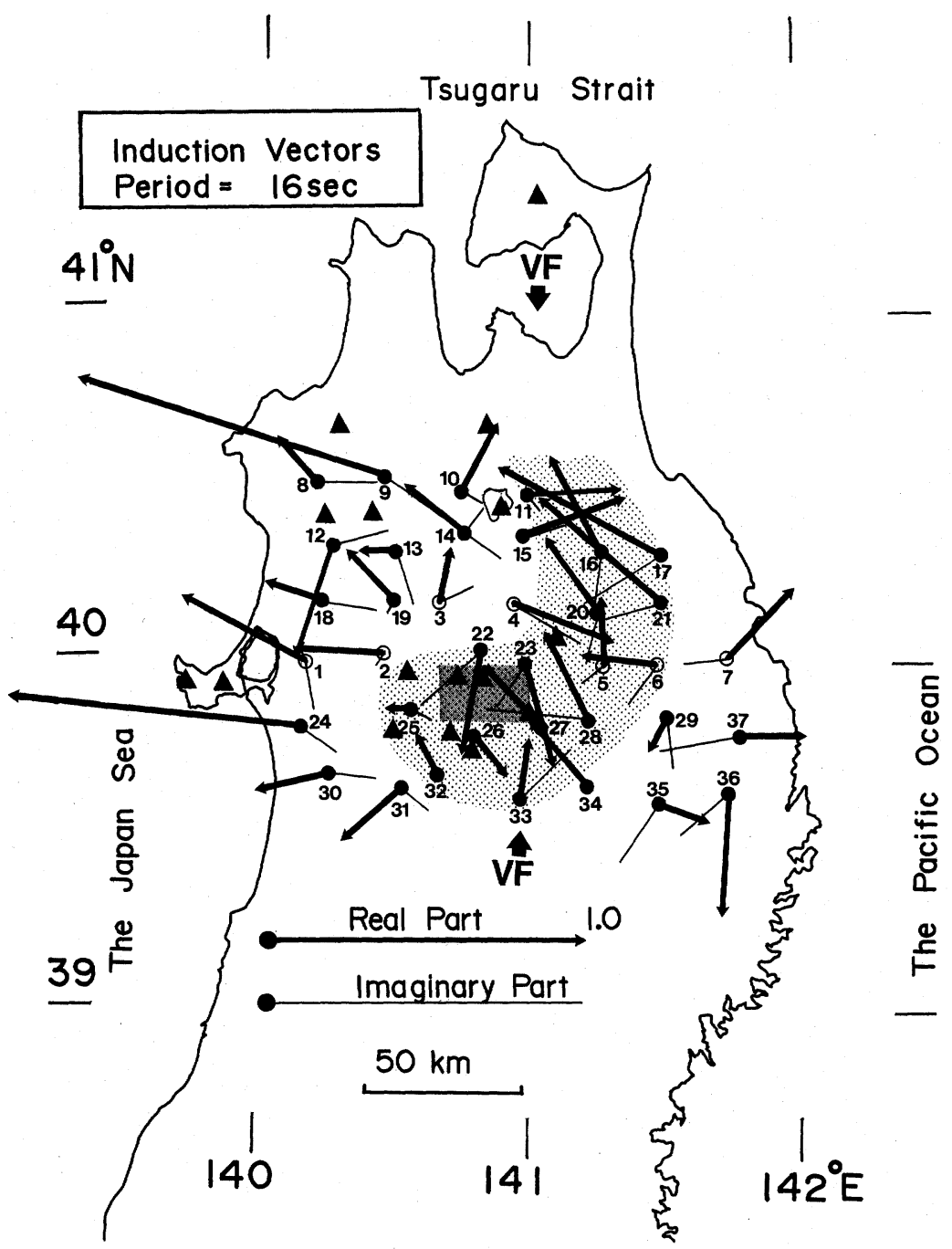

Fig. 4. Induction vectors at the period of $16 \mathrm{sec}$. A conducting belt (NTCB) inferred from induction vectors is shown by dots.

resistivity anomaly beneath the Sengan area, if we compare its vector with those of sites 2 and 31.

In the eastern part, the coastal effect is not significant at sites which are located 20 $\mathrm{km}$ away from the coast line, for instance at sites $17,21,6,29$, and 35 . On the other hand, in the western part of the surveyed area (sites $8,18,1,2,24,30$, and 31 ) the coastal effect is more significant. 
UTADA (1987) and OGAWA (1987) analyzed regional MT data. OGAWA et al. (1987a) and OGAWA and UCHIDA (1987) studied detailed MT data for geothermal explorations. These studies revealed the existence of a low resistivity body in the lower crust beneath the Quaternary volcanic zones in the Tohoku district. The low resistivities inferred from the present study may be due to such a low resistivity anomaly in the lower crust.

\section{Conclusion}

In 1984 and 1985, detailed magnetovariational profilings and magnetotelluric soundings were carried out in the northern Tohoku district. From the analyses of the induction vectors in the period range from $4 \mathrm{sec}$ to $256 \mathrm{sec}$, the following features were found. (1) Regional distribution of induction vectors is primarily due to induced electrical currents in the ocean at periods longer than 64 sec. (2) However, these regional effects are weak to the west of the volcanic front. The area to the west of the volcanic front may have lower resistivity. (3) At the period of $16 \mathrm{sec}$, NTCB including the Sengan geothermal area is clearly delineated as low resistivity anomaly.

Further investigation requires quantitative calculation using two- or threedimensional modeling. Comparison between the inferred conductivity anomaly and other geophysical parameters will be discussed elsewhere (OGAWA et al., 1987b).

SIGMA (System for Interactive Geothermal Mapping and Assessment: IBM4341) of Geological Survey of Japan was used for calculation. This study was conducted under the research program of Exploration Technology of Deep Geothermal Resources in the Sunshine project of Ministry of International Trade and Industry. I appreciate Drs. Seto and Kitamura of Tohoku Institute of Technology, Mr. Kawasaki, Mr. Kubota, Mr. Shiokawa of Sumiko Consultants Co. Ltd. for helping me with the field survey. I am grateful to Dr. Hanaoka, Mr. Murakami, and Mr. Uchida of Geological Survey of Japan for helpful comments throughout this work.

\section{REFERENCES}

Geological Survey of JaPan, Geological Atlas of Japan, 1982.

HonkuRA, Y., Electrical conductivity anomalies beneath the Japan arc, J. Geomag. Geoelectr., 26, $147-171,1974$.

Kato, Y., M. Daguchi, M. Seto, and T. Aruga, Northeastern Japan anomaly of the upper mantle, Sci. Rep. Tohoku Univ., Ser. 5, 21, 19-35, 1971.

OGAWA, Y., Two-dimensional resistivity modeling based on regional magnetotelluric survey in the northern Tohoku district, northeastern Japan, J. Geomag. Geoelectr., 39, 349-366, 1987.

OGAwA, Y. and T. UCHIDA, Resistivity structure beneath the southern part of Onikobe caldera in northeastern Japan, as inferred from the magnetotelluric survey, Butsuri-Tansa (Geophysical Exploration), 40, 22-41, 1987 (in Japanese with English abstract).

OGAWA, Y., Y. MURAKAMI, T. UChida, and N. HANAOKA, Observations of conductivity anomaly along the profile from Gojohme to Fudai (Preliminary report), in Studies on Conductivity Anomaly, pp. 29-34, Geological Survey of Japan, 1985 (in Japanese).

OGAWA, Y., T. YUKUTAKE, and H. UTADA, Two-dimensional modelling of resistivity structure beneath the 
Tohoku district, northern Honshu of Japan, by a finite element method, J. Geomag. Geoelectr., 38, 45-79, 1986.

Ogawa, Y., T. Uchida, T. KIKUChI, and I. Sato, Magnetotelluric survey in the Sengan geothermal area, Rept. Geol. Surv. Japan, 266, 467-503, 1987a (in Japanese with English abstract).

OGAWA, Y., Y. MURAKAMI, T. UCHIDA, Low resistivity anomaly as inferred from regional magnetotelluric survey in the northeastern Japan, to be presented at XIX general assembly International Union of Geodesy and Geophysics, 1987b.

Research Group for Crustal Resistivity Structure, Japan, Preliminary report on a study of resistivity structure beneath the northern Honshu of Japan, J. Geomag. Geoelectr., 35, 589-608, 1983.

Sato, S. and T. SAITo, MT Measurements in Rokuhara, Iwate Pref. and upper mantle conductive structures in the northeastern Japan, Butsuri-Tansa (Geophysical Exploration), 40, 42-57, 1987 (in Japanese with English abstract).

UTADA, H., A direct inversion method for two-dimensional modeling in the geomagnetic induction problem, Ph.D. thesis, 409 pp., University of Tokyo, 1987.

YAMASHITA, H. and I. YoKoYama, Interpretation of the "Northeastern Japan Anomaly" in electrical conductivity of the upper mantle, J. Geomag. Geoelectr., 28, 329-332, 1976. 